„Śląskie Studia Polonistyczne” 2019, nr 1 (13) ISSN 2353-0928 (wersja elektroniczna)

DOI 10.31261/SSP.2019.13.05
Dawid Kujawa

UNIWERSYTET ŚLĄSKI W KATOWICACH

iD https://orcid.org/0000-0001-8124-7301

\section{Feminizm postoperaistyczny i filozofia Luce Irigaray - próba uzgodnienia stanowisk}

Nie jest niczym nowym skonstatowanie faktu, że obecna sytuacja polityczna w Europie i za oceanem stwarza warunki coraz większej opresji wobec przedstawicieli i przedstawicielek mniejszości ${ }^{1}$, które w ostatnich pięćdziesięciu latach konsekwentnie prowadziły walkę z wykluczeniem ekonomicznym, społecznymi uprzedzeniami czy po prostu „niedoreprezentowaniem” konkretnych grup tożsamościowych w sferze publicznej. Jedną z takich mniejszości są kobiety, których roszczenia - w tekście skupię się przede wszystkim na tych dotyczących pracy reprodukcyjnej - coraz głośniej wyrażane publicznie w ostatnich kilku latach, rozbijają się nie tylko o prawicowy (czy też alt-prawicowy) sprzeciw, lecz także - niestety - o ignorancję sporej części aktywistek feministycznych. Tym, co nie pozwala przełożyć praktyki jednorazowych protestów, strajków i okupacji na język organizacji i strategii walk, jest przede wszystkim liberalny model myślenia o zagadnieniach takich jak prawa obywatelskie, cielesna autonomia czy relacje seksualne, który - jak można sądzić, obserwując choćby polską publicystykę feministyczną ${ }^{2}$ - całkowicie zdomi-

1 Gdy piszę o mniejszościach, nie mam oczywiście na myśli kategorii kwantytatywnych, ale kwalitatywny udział danej grupy w „widzialnej” przestrzeni życia publicznego.

2 Chodzi mi tu przede wszystkim o polską odsłonę ruchu \#metoo i publicystykę autorek związanych z „Codziennikiem Feministycznym” (jak Maja Staśko, Patrycja Wieczorkiewicz czy Natalia Broniarczyk). Działaczki te wiele mówią o klasowym wymiarze swoich wystąpień (same siebie nazywają feministkami socjalnymi), ale w rzeczywistości praktyki tych autorek podporządkowane są dyskursowi feministycznemu spod znaku neoliberalnego środowiska Kongresu Kobiet. Nie angażują się one w walki o tańsze żłobki, dłuższe urlopy macierzyńskie czy wyższe zasiłki pielęgnacyjne, a częściej analizują popkulturę, jakby przekonane były o tym, że to treści przekazywane przez głównonurtowe media i przemysł rozrywkowy najsilniej wpływają na bieżącą sytuację kobiet. Z kolei starania, które podejmują, o dostęp do legalnej i taniej aborcji, choć wartościowe, są osadzone w indywidualistycznym światopoglądzie, zgodnie z którym: „moje ciało - moja sprawa”. Wszystkie kobiety powinny mieć dostęp do aborcji na żąda- 
nował współczesny obraz świata lewicy. W takich okolicznościach pogłębiona refleksja nad możliwymi sposobami wyjścia z impasu, stworzenia warunków do realnego oporu, który uderzyłby w słabe punkty aparatu represji, wydaje mi się absolutną koniecznością; nie uważam przy tym, by była to konieczność ściśle teoretyczna, która mogłaby po prostu „uzupełnić” praxis kobiet działających w przestrzeni publicznej. Próby wypracowania skutecznej teorii praw reprodukcyjnych i pracy opiekuńczej, jeśli mają być jakkolwiek użyteczne, muszą być ujmowane jako dyskursywny, ale jak najbardziej praktyczny udział w prowadzonych obecnie walkach.

W niniejszym tekście zestawię z sobą dwie koncepcje, w ramach których odmiennie ujęte zostały relacje między patriarchatem i kapitalizmem, a które w dużym stopniu okazać się mogą dla nas funkcjonalne. Pierwsza z koncepcji stanęła u podstaw prowadzonej w latach siedemdziesiątych ubiegłego wieku kampanii Wages for Housework i wyrasta przede wszystkim z refleksji włoskich postoperaistek, takich jak Silvia Federici, Mariarosa Dalla Costa czy Leopoldina Fortunati ${ }^{3}$. Druga koncepcja, filozoficzna, wiąże się bezpośrednio $\mathrm{z}$ dorobkiem intelektualnym Luce Irigaray, francuskiej myślicielki dawniej związanej ze szkołą Lacanowską, a następnie - po tym, jak Irigaray dokonała gruntownej krytyki Lacana w książce Speculum. De l’autre femme (1974) - właściwie całkowicie wykluczonej z życia uniwersyteckiego, zepchniętej na margines także w akademickim ruchu feministycznym, pochłoniętym wówczas przez nieszczególnie produktywne spory o tzw. esencjalizm4

nie, jednak umocowanie takich roszczeń w liberalnej wolności jednostki niesie z sobą duże ryzyko - postulaty te mogą w przyszłości przyczynić się na przykład do całkowitego przeniesienia kosztów opieki okołoporodowej na „wolne i niezależne” kobiety. Moim celem nie jest deprecjacja wystąpień wymienionych aktywistek: chcę tylko zwrócić uwagę na fakt, że bez wyraźnego zaznaczenia miejsca pracy reprodukcyjnej w procesie akumulacji kapitału nie da się uprawiać feminizmu socjalnego.

3 Kampania Wages for Housework była ogólnoświatowa, poza Włochami prowadzono ją między innymi w Stanach Zjednoczonych (gdzie działała Federici) czy w Wielkiej Brytanii (gdzie kampanię organizowała przede wszystkim Selma James); wymieniam nazwiska Włoszek, jako że teoria cyrkulacji walk stojąca za kampanią jest ściśle związana z operaistyczną, typowo „włoską” lekturą Marksa (Cuninghame, 2010, s. 118-129).

4 „Debata tocząca się niemalże przez całą dekadę lat 80., w centrum której znalazł się spór o tak zwany esencjalizm, godziła nade wszystko w Luce Irigaray. Odnosząc się do wczesnego etapu jej myśli, [...] teoretyczki feministyczne [...] zarzucały filozofce, że projektuje ona apolityczną, ahistoryczną i anachroniczną wizję »kobiecości«. [...] Zarzuty te doprowadziły do uproszczenia postulowanej przez Irigaray koncepcji różnicy płciowej, której znaczenie zawężono do biologicznej różnicy między kobietą a mężczyzną i sugerowano tym samym, iż jej podporą jest jakiś statyczny i normatywny konstrukt płciowości. [...] problem dotyczył znacznie szerszego zjawiska, nie była to bowiem wyłącznie specyfika krytycznego odbioru 
Już teraz zaznaczyć muszę, że porównywanie tych ujęć z konieczności musi obfitować w pewne nieścisłości i nadużycia z mojej strony: pierwsze z tych ujęć powstało bowiem jako broń służąca pracownicom nienajemnym, podczas gdy druga koncepcja ma charakter projektu filozoficznego - pojęcia powracające w obydwu nie zawsze będą zatem odnosiły się dokładnie do tych samych zjawisk. Nie będę próbował wartościować tych ujęć, a skupię się raczej na możliwościach ich wzajemnego wzbogacania się o nowe rozwiązania, ale swoje motywacje dzielił będę z ujęciem postoperaistycznym, które miało na celu przede wszystkim stworzenie właściwych instrumentów do masowych walk prowadzonych poza filozoficznym dyskursem.

\section{Patriarchat jako technologia władzy w kapitalizmie}

Jedną z podstawowych różnic - choć oczywiście nie jedyną - między ortodoksyjnym marksizmem a włoskim marksizmem operaistycznym i postoperaistycznym jest sposób traktowania w obydwu tych tradycjach kategorii klasy: w pierwszej z nich mamy do czynienia z bardzo statycznym ujęciem klasy robotniczej, które odnosi się do pracowników najemnych, wytwarzających wartość dodatkową w procesie pracy produkcyjnej - wartość ta następnie jest im odbierana i wypłacana jedynie w pewnej części w postaci płacy. Taki sposób odczytywania akumulacji kapitału, jak łatwo się domyślić, wyklucza z tego procesu jakikolwiek udział pracowników nienajemnych. Oznacza to, że nawet tradycja socjalistycznego feminizmu - choć w jej ramach zwraca się uwagę na pracę domową, pracę reprodukcyjną czy problem przemocy domowej-sytuuje większość pracy wykonywanej przez kobiety poza ruchem okrężnym kapitału. Marks, jak zauważa między innymi Silvia Federici, nie pomijał w swoich tekstach kwestii kobiecej, ale ujmował ją w sposób, który nie był wolny od znaczących przeoczeń (FEDERICI, 2017).

Kategoria składu klasowego i jego rekompozycji pozwoliła spojrzeć na kwestię kobiecą z zupełnie innej perspektywy. Operaizm wprowadził do obiegu pojęcia składu technicznego i politycznego, a w ten sposób umożliwił bardziej dynamiczne ujmowanie zagadnienia walki klasowej: techniczny skład klasowy, najkrócej rzecz ujmując, dotyczy warunków, w jakich wytwarzana jest wartość dodatkowa, a zatem kwalifikacji robotników, ich relacji z kapitałem stałym, organizacji czasu pracy - wszystkiego tego, co pozwala dyscyplinować pracowników i wpływać na ich wydaj-

prac Irigaray, ale raczej sposobu tworzenia narracji teorii feministycznych przez krytykę anglo-amerykańską. W tym przypadku chodziło o tak zwane narracje progresywne, snute wokół drugiej fali feminizmu i French Feminism" (SzopA, 2018, s. 59-60). Więcej na temat debaty konstruktywizm - esencjalizm w: SzopA, 2018, s. $59-96$. 
ność; skład polityczny z kolei odnosi się do sposobów organizowania się pracowników, ich zdolności (potentia) do przeciwstawiania się kapitalistycznemu wyzyskowi, dokonywania samowaloryzacji i ustanawiania własnej autonomii. Skład polityczny zawsze determinowany jest przez skład techniczny, podobnie jak skład techniczny zawsze stanowi swoistą odpowiedź na nowe formy samoorganizacji robotników (WRIGHT, 2002). Między innymi ta koncepcja pozwoliła postoperaistom na specyficzne odczytanie mobilizacji tzw. Nowej Lewicy i związanych z nią alianckich ruchów - walki czarnoskórych, feministek czy mniejszości seksualnych nie były w ramach tej tradycji odczytywane jako jałowe batalie o uznanie, o większą reprezentację danych grup w nienaruszonej strukturze społecznej kapitalizmu, batalie dotyczące wyłącznie - mówiąc językiem ortodoksów - kapitalistycznej nadbudowy, ale jako wystąpienia uderzające bezpośrednio we władzę kapitału, wyraźnie sygnalizujące dokonującą się właśnie rekompozycję składu klasowego. Związanym z tymi procesami zagadnieniem, które szczególnie interesowało feministki, była kwestia zupełnie niedostrzegana w klasycznych lekturach Marksa - kwestia udziału pracy nienajemnej w akumulacji kapitału (DALla Costa, JAMES, 1975; Fortunati, 1995; Weeks, 2011; Federici, Austin, eds., 2018). Dobrze zobrazować można to zagadnienie przy użyciu Marksowskiego schematu obrotu kapitału, uzupełnionego później przez Harry’ego Cleavera o zagadnienie pracy reprodukcyjnej:

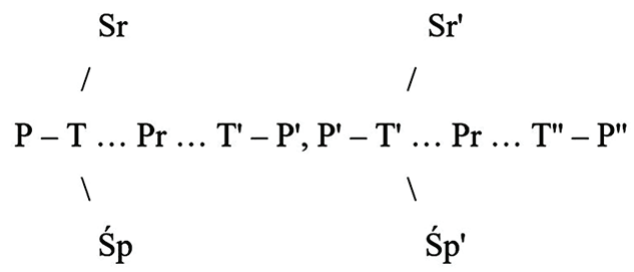

Ryc. 1. Ruch okrężny kapitału (CLEAVER, 2011, s. 112; por. MARKS, 1955, s. 25). OBJAŚNIENIA: P - pieniądz; Pr - produkcja; Sr - siła robocza; Śp - środki produkcji; T - towar.

Okrężny ruch kapitału opisany przez Marksa opiera się na prostym założeniu: pieniądz inwestowany jest przez kapitalistę w dwa rodzaje towaru, bez których proces produkcji nie może ruszyć: siłę roboczą (kapitał zmienny) i środki produkcji (kapitał stały). W efekcie produkcji kapitalista otrzymuje wzbogacony o wartość dodatkową towar gotowy do sprzedaży; kapitał uzyskany w ten sposób kapitalista częściowo przeznacza na konsumpcję własną, częściowo zaś na ponowną inwestycję: zakup siły roboczej i zakup lub konserwację środków produkcji. Marks był oczywiście świadom tego, że siła robocza pracowników reprodukowana jest 
poprzez konsumowanie płacy, nie dostrzegł jednak tego, co z feministycznej perspektywy okazuje się absolutniekluczowe: faktu, że za reprodukcją siły roboczej stoi również realna, tyle że nieopłacona, praca.

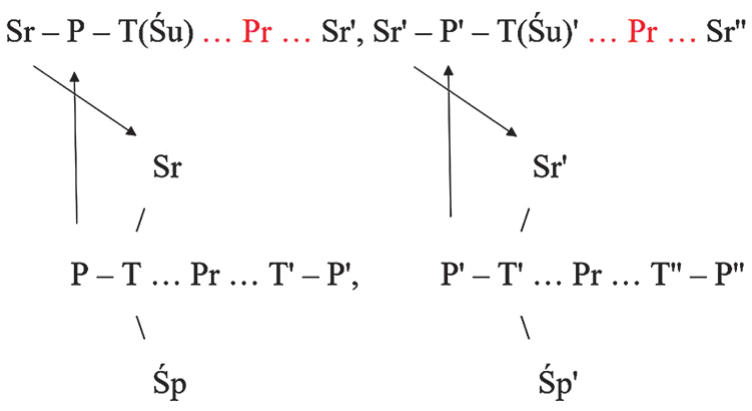

Ryc. 2. Reprodukcja siły roboczej (CLEAVER, 2011, s. 159).

OBJAŚNIENIA: P - pieniądz; $\mathrm{Pr}$ - produkcja; Sr - siła robocza; Śp -środki produkcji; T-towar; $\mathrm{T}(\mathrm{S} u)$ - środki utrzymania.

Postoperaistki wykazały, że praca nienajemna, dotąd nieuwzględniana w ruchu okrężnym kapitału - praca domowa, seksualna, afektywna, ale także edukacja pobierana przez uczniów i studentów nie powinna być ujmowana jako zewnętrzna wobec kapitalistycznej ekstrakcji wartości dodatkowej z prostego powodu: praca nienajemna jest fundamentalna dla kapitalistycznej produkcji, bez pracy nienajemnej bowiem nie może być mowy o jakiejkolwiek pracy najemnej. To w ramach nieodpłatnej, niewidocznej pracy następuje produkcja i reprodukcja jedynego towaru, jakim dysponuje pracownik najemny - siły roboczej.

Brak płacy za pracę reprodukcyjną nie jest rzecz jasna czymś przypadkowym: pozwala wprowadzić wewnętrzną hierarchię w obrębie klasy robotniczej (w heterodoksyjnym marksizmie ujmowanej szeroko, nietylko w odniesieniu do pracowników najemnych), a tym samym niejako oddelegować mechanizmy dyscyplinowania pracowników nienajemnych. Choć u podstaw kapitalistycznejakumulacji stoi produkcja siły roboczej, to nie kapitaliści nadzorują i przywołują do porządku odpowiedzialne za nią pracownice: tym zajmować mają się sami robotnicy, którzy do dyspozycji dostają cały zestaw narzędzi wywodzących się z długiej tradycji patriarchalnego ucisku. Dopiero z tego miejsca oczywiste staje się to, czego liberalne feministki nigdy nie były w stanie dostrzec: gwałty, przemoc psychiczna i ekonomiczna nigdy nie są jednostkowymi ekscesami, ale stanowią absolutną podstawę funkcjonowania patologicznego systemu. Patriarchat w ujęciu postoperaistek jest oczywiście o wiele starszy niż sam kapitalizm, w kapitalizmie przyjmuje jed- 
nak postać specyficznej technologii władzy, która pozwala kapitalizmowi przetrwać i uniknąć licznych kryzysów.

\section{Różnica płciowa i koniec pracy}

W słynnym passusie z Manifestu Partii Komunistycznej, w którym Marks i Engels komentują hipokryzję burżuazyjnych frazesów o więzach rodzinnych, czytamy: „Ale wy, komuniści, chcecie wprowadzić wspólność żon - wrzeszczy chórem cała burżuazja. Burżua widzi w swej żonie zwykłe narzędzie produkcji. Słyszy, że narzędzia produkcji mają być wspólnie użytkowane, i naturalnie nie może sobie wyobrazić nic innego niż to, że ten sam los spotka także kobiety. Nie domyśla się, że chodzi właśnie o to, by znieść taką sytuację kobiety, w której jest ona zwykłym narzędziem produkcji" (MARKs, ENGELS, 2007, s. 12). Z fragmentem tym bez wątpienia koresponduje jeden z najpopularniejszych tekstów Luce Irigaray, Rynek kobiet, w którym filozofka, odnosząc się do badań Lévi-Straussa i stosując marksistowski aparat pojęciowy, wskazuje na miejsce kobiet w gospodarce kapitalistycznej. Ujęcie problemu przez Irigaray w pewnym zakresie pozostaje kompatybilne $\mathrm{z}$ analizami postoperaistek, choć akcenty rozłożone zostały tu nieco inaczej, w związku z czym nie są to perspektywy zgodne w stu procentach.

Irigaray zwraca uwagę przede wszystkim na fakt, że w kapitalistycznym społeczeństwie kobieta funkcjonuje jako towar, posiada zatem swoją wartość wymienną (jako dziewica lub prostytutka) i wartość użytkową (jako matka). Zagadnienia wymiany kobiet i zakazu kazirodztwa, które mają w tym ujęciu stanowić fundament porządku symbolicznego, zostały opisane w literaturze, nie będę więc poświęcał szczególnej uwagi rekonstrukcji tych pojęć (ARASZKIEWICZ, 2003). O wiele bardziej zajmujące wydaje mi się to, że niewiele mówiono dotąd na temat proponowanej przez Irigaray koncepcji wartości użytkowej kobiety towaru i o konsekwencjach stosowania tej koncepcji w analizie patriarchatu i kapitalizmu:

wszelkie ustroje społeczne w toku „dziejów” funkcjonują, opierając się na wyzysku pewnej „klasy” wytwórców, mianowicie kobiet. Ich reprodukcyjna wartość użytkowa (dzieci, siły roboczej) wraz z przemianą w wartość wymienną podtrzymuje porządek symboliczny jako taki, choć kobiety nie są za ową "pracę" w podobnej walucie wynagradzane. To bowiem pociągałoby za sobą rozbicie systemu wymian, czyli rozkład monopolu imienia własnego [...] sprawowanego przez mężczyzn-ojców (IRIGARAY, 2010a, s. 145-146). 
Perspektywa proponowana przez autorkę Speculum, jak widać, w punkcie wyjścia ma kilka założeń zbieżnych z postoperaistycznym ujęciem wyzysku pracy nienajemnej: wartość użytkowa kobiety towaru w kapitalizmie jest związana przede wszystkim $\mathrm{z}$ reprodukcją siły roboczej, która dla akumulacji kapitału jest niezbędna, a zatem stoi u podstaw funkcjonowania systemu kapitalistycznego w ogóle. Jedna kwestia pozostaje tu jednak problematyczna i wymaga głębszego namysłu: o ile postoperaistki opisują pracę reprodukcyjną w kategoriach nienajemnej pracy czynnie uczestniczącej w produkcji wartości dodatkowej, Irigaray łączy ten rodzaj pracy ściślej z towarowym sposobem istnienia kobiety skutki tego są znaczące, Irigaray bowiem w ten sposób bagatelizuje towarowy charakter siły roboczej jako takiej, a zatem nadaje podmiotowy charakter męskiemu wytwórcy, choć w kapitalistycznym systemie wyalienowany robotnik zostaje przecież w dużym stopniu pozbawiony sprawczości i zredukowany do siły roboczej - jedynego towaru, jaki może zaproponować kapitaliście na sprzedaż. Zdawać by się mogło zatem, że Irigaray czyni kapitalizm bardziej „ludzkim” w stosunku do męskiego robotnika, który w tej optyce jest czymś więcej niż tylko utowarowioną siłą roboczą. W moim przekonaniu nie jest to jednak nieścisłość w wywodzie filozofki, a raczej działanie celowe, które pozwala jej na przeprowadzenie dobrze przemyślanej argumentacji - argumentacji, która ma wyraźny związek z teorią wartości opartej na pracy.

Właściwym celem Irigaray nie jest wcale przedstawienie pracownika najemnego jako całkowicie upodmiotowionego beneficjenta podrzędnej pozycji kobiety w kapitalizmie (MARTIN, 2004, s. 24), ale zwrócenie uwagi na fetysz pracy produkcyjnej, z którym mamy do czynienia zarówno w kapitalistycznej gospodarce, jak i w ortodoksyjnej marksistowskiej krytyce kapitalistycznego sposobu produkcji. Wyzwanie, jakie teorii wartości rzuca feminizm postoperaistyczny, dotyczy - wcześniej zupełnie lekceważonego - udziału pracy reprodukcyjnej w kapitalistycznej akumulacji, z kolei wyzwanie, jakie teorii wartości rzuca filozofia Irigaray, dotyczy samego prymatu produkcji nad reprodukcją i stojącego za nim Arystotelesowskiego prymatu formy nad materią (MARTIN, 2004, s. 23). W tym sensie francuska myślicielka zwraca uwagę na palący problem postfordowskiego kapitalizmu, który współcześnie jest przedmiotem licznych dyskusji i z biegiem czasu w coraz większym stopniu ujawnia się jako kluczowy dla naszych przyszłych form współbycia - mowa o pracy opiekuńczej, rozumianej nie tyle jako warunek reprodukcji siły roboczej w kapitalizmie, ile jako konieczny punkt wyjścia w rozważaniach nad wszelkimi możliwymi kształtami postkapitalistycznej formacji społecznej. Użyteczność proponowanego przez Irigaray pojęcia różnicy płciowej w tym zakresie jest niekwestiono- 
wana: jeżeli koncepcja produkcji wartości dodatkowej oparta jest na fallogocentrycznym porządku symbolicznym, wówczas wykroczenie poza kapitalistyczną eksploatację (rozumianą najszerzej: jako podporządkowywanie chaotycznej materii zorganizowanej, ludzkiej działalności) wymaga pogłębionego namysłu nad tym, gdzie szukać możemy fundamentów innego, przyszłego porządku społecznego. Irigaray nie ma co do tego wątpliwości: konieczne jest przejście „na drugą stronę lustra podtrzymującego wszelka spekulację” (IRIGARAY, 2010c, s. 64). „To w nieredukowalnym wymiarze różnicy płciowej dostrzega ona [Irigaray - D.K.] strategiczne otwarcie na wielość i różnorodność, jako że »dwa nigdy nie dzieli się na dwie jedności. Związki opierają się podziałom na jednostki« [...]. Ta niepodzielność i niesprowadzalność do jedności sugeruje, że jednostka to zawsze »więcej niż jedno « - bo jest i zwielokrotniona w sobie, i otwarta na aspekt relacyjny, co samo w sobie kwestionuje już podział na wnętrze i zewnętrze. [...] Skoro płciowość jest tym wymiarem egzystencji, który wytycza granice świata, uniemożliwiając w ten sposób wszelkie myślenie w kategoriach całości, to otwiera perspektywę na to, co wykracza poza dany horyzont. Uznanie własnej płciowości wiąże się zatem z uznaniem własnej skończoności, co skutkuje otwarciem na inny świat" (SzopA, 2018, s. 179). Filozofka opowiada się zatem po stronie materii nieuformowanej w zgodzie z paradygmatem, na którym wzniesiona została „hom(m)oseksualna" kultura. To, co - zgodnie z optyką Irigaray - obecnie stanowi jedynie „wartość użytkową" kobiety towaru, nie tylko musi zostać ujawnione jako fundament kapitalistycznej akumulacji, bez którego ta nie może się obejść, lecz musi także przekroczyć horyzont patriarchalnej spekulacji i stać się - już poza formą towarową - podłożem dla społeczeństwa opartego na życiodajności troski (féconditéde la caresse $)^{5}$. Bez wątpienia to właśnie ma na myśli Irigaray, gdy pisze o możliwym świecie, w którym towary sprzeciwiają się pójściu na rynek:

natura wydatkowałaby się, zarazem nie wyczerpując się; wymieniałaby się bez pracy; darowałaby się - w ukryciu przed męskimi transakcjami - niczego nie żądając w zamian:

5 Mam tu na myśli tekst Luce Irigaray zatytułowany The Fecundity of the Caress (IRIGARAY, 1993). Ze względu na skrótowy charakter tego artykułu pominąć muszę tu kwestię, która obecnie stanowi prawdopodobnie najważniejszy wątek $\mathrm{w}$ debatach na temat emancypacyjnego charakteru dowartościowania pracy reprodukcyjnej - chodzi oczywiście o ściśle związane z postfordowskim przekształceniem kapitalizmu zagadnienie subsumpcji pracy opiekuńczej czy afektywnej i zaprzęgnięcia w proces produkcji wartości dodatkowej życia jako takiego (Morini, Fumagalli, 2011). 
bezinteresowne przyjemności, błogość bez znoju, rozkosz bez potrzeby posiadania (IRIgARAY, 2010b, s. 165).

Wszystko wskazuje więc na to, że myśl Irigaray można czytaćjako projekt filozoficzny, za którym stoją postulaty niezwykle bliskie współczesnym teoretykom dóbr wspólnych (commons) ${ }^{6}$ : naczelne zadanie dla ruchów antykapitalistycznych (a zatem - jak wynika ze wstępnych założeń stojących za pojęciem różnicy płciowej - uderzających także w patriarchat) filozofka widzi bowiem nie w działaniach zmierzających do natychmiastowego obalenia systemu opartego na „ruchu spiralnym”, na nieskończonej akumulacji, ale w niestrudzonym tworzeniu innego porządku społecznego; w porządku tym reprodukcja (wartość użytkowa kobiety towaru) nie służyłaby wytwarzaniu i zachowywaniu siły roboczej pracownika najemnego, sprzedawanej następnie na rynku, ale dalszej reprodukcji życia całkowicie wolnego od konieczności sprzedawania siły roboczej. Społeczeństwo, które kolektywnie dąży do samozachowania wskutek wspólnego wysiłku reprodukcyjnego bez generowania wzrostu (a zatem społeczeństwo bez pracy najemnej), byłoby w jej perspektywie społeczeństwem daru bez długu, a nie obliczonej na zysk transakcji.

Choć strategia prowadzenia walki stojąca za kampanią Wages for Housework i Irigariańska koncepcja różnicy płciowej pochodzą nie-

6 „Choć commonsy istnieją tu i teraz, ich dalszy rozwój i splot może umożliwić nam odpowiedź na nieunikniony kryzys kapitalizmu i katastrofę klimatyczną w sposób, który wzmocni autonomię commonsów względem kapitału i państwowej logiki odgórnej organizacji. Jedna szczególna grupa aktywności commonsów, jak sądzę, musi odgrywać tu uprzywilejowaną rolę - chodzi o wszystkie te aktywności, które bezpośrednio służą reprodukowaniu życia, zarówno ludzkich istot, jak i natury. Wspólnoty reprodukcyjne [commons of reproduction] już teraz są spontanicznie tworzone przez wielu zwykłych ludzi na całym świecie, aby odpowiedzieć na niedobory, potrzeby lub aspiracje w zakresie dostępu do zdrowej żywności, mieszkalnictwa, wody, opieki społecznej i edukacji. Ale poza ich odpowiedziami na potrzeby, wierzę, że dalszy rozwój tych i podobnych im commonsów będzie na tyle istotną wartością strategiczną, że pozwoli stworzyć materialną podstawę dla renesansu commonsów w wielu sferach [...]. A to dlatego, że nie tylko przyniosą nam one korzyści w zakresie [tworzenia] nowych społeczności, nowych kultur i nowych metod budowania dobrostanu, bezpieczeństwa i zaufania w ramach złożonej organizacji; będą one także chroniły nas przed kaprysami rynków finansowych, a przede wszystkim zwiększą one nasze bezpieczeństwo i siłę, byśmy mogli odmówić dalszej eksploatacji na kapitalistycznych rynkach. Im większa jest zdolność kapitału do szantażowania nas poprzez gorsze warunki, mniejsze bezpieczeństwo i coraz bardziej wyczerpujący rytm pracy, tym mniej mamy siły, by odrzucić jego logikę. I odwrotnie, siła ta rośnie wraz z pojawianiem się alternatywnych środków naszej reprodukcji" (DE ANGELIs, 2017, s. 13-14). 7 „Konkretnie rzecz biorąc, akumulacja sprowadza się do reprodukcji kapitału w rozszerzającej się skali. Ruch okrężny reprodukcji prostej modyfikuje się i przekształca, według wyrażenia Sismondiego, w spiralę" (MARKs, 1951, s. 626). 
jako z różnych porządków - ta pierwsza jest bowiem bronią oddaną w ręce pracownic nienajemnych, a druga pojęciem filozoficznym zmuszającym nas do przewartościowania jedno-męsko-płciowej tradycji myślenia - w gruncie rzeczy mogą one być kompatybilne. Jeżeli domaganie się płacy za pracę reprodukcyjną uznamy za działanie „tu i teraz” destabilizujące kapitalistyczną akumulację, wówczas pogłębiona refleksja nad różnicą płciową okaże się jednym z wielu projektów filozoficznych, które pozwalają wyznaczyć ostateczny horyzont takich działań - jeżeli wyjście poza paradygmat nieograniczonej akumulacji będzie kiedykolwiek możliwe, ów inny porządek będzie musiał znaleźć oparcie w autonomicznym względem kapitału procesie reprodukcji życia jako takiego ${ }^{8}$. Nie chodzi tu rzecz jasna o gotowy, zamknięty projekt społeczeństwa komunistycznego, ale o „rzeczywisty ruch, który znosi stan obecny” (MARKs, ENGELS, 1961, s. 38) - ruch, który swobodną ludzką działalność prowadzącą ku samozachowaniu uwolni od jej produkcyjnego charakteru, a społeczne bogactwo od jego towarowej formy. Sytuując zagadnienie pracy reprodukcyjnej w punkcie wyjścia zarówno codziennych walk, jak i praktyk dyskursywnych, wykonujemy pierwszy krok na drodze ku tak rozumianej emancypacji.

\section{Bibliografia}

Araszkiewicz Agata, 2003: Poza zakazem kazirodztwa. „Przegląd Filozoficzno-Literacki", nr 1.

Cleaver Harry, 2011: Polityczne czytanie „Kapitału”. [Przeł. Iwo Czyż]. Poznań: Oficyna Wydawnicza Bractwa „Trojka”.

Cuninghame Patric, 2010: Włoski operaismo i autonomia lat 70. Walka przeciwko nieopłacanej pracy reprodukcyjnej i przemocy. „Przegląd Anarchistyczny", nr 11 (wiosna/lato).

Dalla Costa Mariarosa, James Selma, 1975: The Power of Women and the Subversion of the Community. London: Butler and Tanner Ltd.

De Angelis Massimo, 2017: Omnia sunt Communia. On the Commons and the Transformation to Postcapitalism. London: Zed Books.

Federici Silvia, 2017: „Kapitał” a płeć. Przeł. Jakub Krzeski, Anna PIeKARSKA. „Praktyka Teoretyczna”, nr 3.

FEDERICI Silvia, Austin Arlen, eds., 2018: Wages for Housework: The New York Committee 1972-1979. History, Theory, Documents. 2nd ed. New York: Autonomedia.

8 Mogłoby to w jakimś stopniu tłumaczyć skoncentrowanie Irigaray na relacjach matka - córka, które liberalne feministki odczytywały jako konserwatywną apologię matyczności (IRIGARAY, 1993b, 2000). 
Fortunati Leopoldina, 1995: Arcane of Reproduction: Housework, Prostitution, Labour and Capital. Trans. Hilary CREEk. New York: Autonomedia.

GRAEBER David, 2014: Czas na rewoltę klas opiekuńczych? Rozmowę przeprowadził Thomas Frank. Przeł. Łukasz MolL. „Praktyka Teoretyczna”. [Online:] http://www.praktykateoretyczna.pl/david-grae ber-thomas-frank-czas-na-rewolte-klas-opiekunczych/ [20.11.2018].

IRIGARAY Luce, 1993a: The Fecundity of the Caress. In: EADEM: An Ethics of Sexual Difference. Trans. Carolyn Burke, Gillian C. Gill. Ithaca, New York: The Athlone Press.

IRIGARAY Luce, 1993b: Sexes and Genealogies. Trans. Gillian C. GILL. New York: Columbia University Press.

IRIGARAY Luce, 2000: Ciało w ciało z matką. Przeł. Agata ARASzkiewicz. Kraków: Wydawnictwo eFKa.

IRIGARAY Luce, 2010a: Rynek kobiet. W: EADEM: Ta płeć (jednq) płcią niebędąca. Przeł. Sławomir KróLAK. Kraków: Wydawnictwo Uniwersytetu Jagiellońskiego.

IRIGARAY Luce, 2010b: Towary między sobą. W: EADEM: Ta płeć (jednq) płcią niebędąca. Przeł. Sławomir KróLAK. Kraków: Wydawnictwo Uniwersytetu Jagiellońskiego.

IRIGARAy Luce, 2010c: Władza dyskursu. Podporządkowanie kobiecości. W: EADEM: Ta płeć (jedną) płcią niebędąca. Przeł. Sławomir KRóLAK. Kraków: Wydawnictwo Uniwersytetu Jagiellońskiego.

MARKs Karol, 1951: Kapitat. Krytyka ekonomii politycznej. T. 1: Ksiega II: Proces wytwarzania kapitału. [Red. Paweł HoffMAN, Bronisław Minc, Edward LipıŃski]. Wyd. 3. Warszawa: Wydawnictwo Książka i Wiedza.

MARKs Karol, 1955: Kapitat. Krytyka ekonomii politycznej. T. 2: Księga II: Proces cyrkulacji kapitału. [Tłum. Julian MaLINIAK. RED. Ozjasz Szechter, Eugenia Wolicka]. Warszawa: Wydawnictwo Książka i Wiedza.

MARKs Karol, Engels Fryderyk, 1961: Ideologia niemiecka. W: IIDEM: Dzieła. T. 3. Przeł. Jerzy Dewitz et al. Warszawa: Wydawnictwo Książka i Wiedza.

MARKs Karol, Engels Fryderyk, 2007: Manifest Partii Komunistycznej. Studenckie Koło Filozofii Marksistowskiej (Uniwersytet Warszawski). Warszawa. [Online:] https://www.ce.uw.edu.pl/wp-content/ uploads/2018/10/4.-kapitalizm_marks_engels_manifest-komunistyczny.pdf [9.04.2019].

MARTIN Alison, 2004: European Initiative: Irigaray, Marx, and Citizenship. „Hypatia”, vol. 19, no. 3.

Morini Cristina, Fumagalli Angela, 2011: Life Put to Work: Towards a Life Theory of Value. Trans. Emanuele LEONARDI. [Online:] http:// www.ephemerajournal.org/contribution/life-put-work-towardslife-theory-value [20.11.2018]. 
Szopa Katarzyna, 2018: Poetyka rozkwitania. Różnica płciowa w filozofii Luce Irigaray. Warszawa: Instytut Badań Literackich PAN. Wydawnictwo.

WeEks Kathi, 2011: The Problem with Work. Feminism, Marxism, Antiwork Politics, and Postwork Imaginaries. Durham-London: Duke University Press.

WRIGHT Steve, 2002: Storming Heaven. Class composition and Struggle in Italian Autonomist Marxism. London-Sterling: Pluto Press.

\section{Dawid Kujawa}

\section{Post-Operaist Feminism and Luce Irigaray's Philosophy - an Attempt at Reconciling Stances}

Summary: In the present article the author endeavours to compare the main assumptions of Italian post-operaist feminism (mostly those related to the Wages for Housework campaign) with Luce Irigaray's sexuate difference philosophy. Assuming as a departure point the notion of labour force reproduction, the author tries to prove the synergic potential sustaining between the two mentioned perspectives - the most noteworthy convergence between them is the eventually shared ontological horizon stemming from Marx's perspective on communism as "the real movement which abolishes the present state of things."

Keywords: post-operaism, sexuate difference, Luce Irigaray, Wages for Housework, reproduction

\section{Dawid Kujawa}

\section{Féminisme postopéraïste et la philosophie de Luce Irigaray - une tentative d'accorder les positions}

Résumé : L'article essaye d'accorder les questions principales du féminisme italien postopéraïste (avant tout dans la mesure de la campagne de Wages for Housework) avec la philosophie de la différence sexuelle de Luce Irigaray. En partant de la notion de la reproduction de la main d'œuvre, l'auteur tente de démontrer une possibilité d'enrichissement réciproque des deux perspectives - un pareil horizon ontologique ayant source dans la présentation de Marx du communisme en tant qu'« un véritable mouvement qui neutralise l'état actuel » est un élément qui les relie étroitement.

Mots clés : postopéraïsme, différence sexuelle, Luce lrigaray, Wages for Housework, reproduction 